\title{
Amsterdam as a Changing Node in Financial Services
}

\section{Marina van Geenhuizen, Delft}

\section{Introduction}

The Netherlands is one of the smallest countries in the European Union. Its territory measures $41,500 \mathrm{~km}^{2}$, with a maximum north-south distance of approximately $300 \mathrm{~km}$ and maximum east-west distance of 200 $\mathrm{km}$. There are four relatively large cities in The Netherlands, all located in the western part (Randstad). There are no big cities, like Paris and London; rather, the four large cities act as a network based on a certain economic specialization. The largest city of The Netherlands is Amsterdam, with 718.000 inhabitants in the municipality and 1.110 .000 inhabitants in the agglomeration.

In this article we will investigate the development of the position of Amsterdam by focusing on a specific urban economic sector - financial services. The question addressed is how Amsterdam has developed in the past decade as a node - in a national and international context - and how this development can be understood both theoretically and empirically. In addition, the future of Amsterdam in e-economy is addressed. The analysis includes a look at current opportunities and threats for new economic activity in the field of information and communication technologies (ICTs), using insights gained from the same theoretical background as the financial services sector.

The past few years have seen the rise of widely different views about the future of cities in an environment marked by rapidly converging computing, communication and media technologies (vAN GEENHUIZEN \& Nijkamp 2001, Graham \& Marvin 1997). In one extreme scenario - the "death of distance» - households and firms become «footloose», that is there is no need for proximity to activity in cities. In this situation, large industrial cities weaken their hold over economic and social life (CAIRNCross 1997). Urban meeting places, working places, markets, entertainment, etc., give way to virtual gathering places, teleworking, e-business, information exchange and entertainment spots for plugged-in customers (MITCHell 1995). The other extreme scenario forsees that large cities in the economic core strengthening their position at the expense of smaller ones. This scenario recognizes the role of large corporations in decision making in the global economic system, and the fact that their activity - requiring face-to-face contact - may hinder any trend for spread. Most probably there will only be a few such «global urban command centers» in which highly qualified professional skills and tacit knowledge are produced and circulate (Graham 1999, SASSEN 1999). ICTs help to extend the dominance of these cities by enabling action at a distance, and remote control of smaller towns and rural places.

There is also a more general discussion about forces leading to a spread of economic activity. Empirical results in The Netherlands and Europe point towards competition between larger and smaller cities (e.g. Lambooy 1998), where the larger cities are the «losers» mainly due to diseconomies of scale. However, what may be happening is that large cities are extending their sphere of influence over larger distances with concentration at a higher spatial scale, based on location factors like agglomeration economies and knowledge spillovers, alongside a favorable institutional environment.

This article starts with a brief reflection on theory of benefits from urban agglomeration and knowledge spillovers. It proceeds with an empirical analysis of the position of Amsterdam in financial services over time. Results are derived from employment indicators using official statistics and from various indicators produced by the sector, such as headquarter location, balance sheet totals and activities of the Stock Exchange, all commonly used in research on financial centers (e.g. Leyshon \& Thrift 1997, Martin 1999). The empirical analysis is also based on in-depth interviews at the corporate level of banking organizations to identify local factors and processes at work. The results on the financial sector are original ones, i.e. derived by the author, whereas the results on ICT-activity are mainly from recent literature. The paper concludes with policy implications regarding the supporting local «milieu».

\section{Theoretical Reflections}

Today and certainly also in the past decade financial services operate in a highly uncertain environment. This is due to growing competition from new entrants from other sectors, other countries and e-activity (e-banks), the penetration of new technologies, and macro-economic and financial cycles. Uncertainty holds particularly for activities like lead management of syndicates, leading mergers, management buy-outs, portfolio management for investors, swap transactions, and stock trade in large amounts and in locally listed shares (e.g. Hart, Ter \& Piersma 1990).

By following Marshall in the recognition of positive 
externalities at the level of individual firms, the notions of agglomeration economies and information spillovers seem useful. Agglomeration economies include firstly, cost reductions of firms in the same industry based upon the larger scale and a more efficient division of labor, and secondly, cost reductions based upon a differentiated structure of economic activity and a differentiated labor market. Agglomeration economies thus point to scale and differentiation (scope) as favorable attributes of large cities. The notion of increasing returns is closely related in that it refers to the dynamic and cumulative advantages of spatial proximity. In terms of scale of production it means decreasing unit costs related to production increase. In terms of innovation it means an easier (cheaper) adoption in places where other firms (have) experience(d) a similar learning curve (ARTHUR 1996).

Knowledge spillovers refer to the phenomenon that knowledge - as a non-rivaling and non-excluding good - generates benefits for third parties. In this context a distinction needs to be made between codified knowledge and tacit knowledge. The former includes, for example, facts, figures, and laws, and can be transferred by documents, databases, formulas, etc. Marginal costs of transfer of codified knowledge over distance seem to be decreasing due to technical developments in ICTs. By contrast, tacit knowledge cannot be easily stored and transferred, because it refers to «know how» and "know who», for example, the way to apply customized software and the way to benefit from particular informal networks (VAN Geenhuizen \& NiJKamp 2000). This type of knowledge which is specific for individuals and firms in terms of habits and culture, seems increasingly important in problem-solving and innovation (e.g. VON HIPPEL 1994). The more important tacit knowledge, the more important spatial proximity, because the knowledge - as embodied in persons - can only be transferred in close human interaction (e.g. AUDRETSCH 1998). Although some progress has been made in electronic communication - using intelligent agents and multimedia alongside interactive tools - the obstacles to distributed transfer of tacit knowledge remain substantial (BolisanI \& SCARSo 2000).

The above reasoning points to large cities as attractive locations for non-routine production and innovation. Cities with the highest hierarchical rank are generally in the best position for concentration of these activities (Glaeser 1998, Sassen 1999). With regard to the labor market, financial services benefit from the availability of large amounts of highly skilled labor, meaning a quicker filling of vacancies and a greater choice of applicants. In return, highly specialized financial workers prefer to be in financial centers because of the abundance of career opportunities available. As con- cerns the need for intermediate services, financial firms at the (inter)national level use specialized producer services, such as hardware and software services, and sophisticated legal advice (Porteous 1999). Proximity may cause better (timely) services and lower prices. A more recent factor needs to be added here, i.e. access to global communication networks (Graham 1999). Due to the influence of privatization and liberalization, advanced telecommunication infrastructure is increasingly made available only there where market demand is high, i.e. in the largest cities. Further, in terms of knowledge spillovers, proximity of financial firms means the following: Localized innovation is a source of positive externalities, both in the sense of new financial products and new ways of doing things including complex problem-solving. There are also spillovers concerning what other firms are doing and what is going on in the sector (PorTEOus 1999). From a socio-cultural perspective, financial services are typically operated through rules and norms of behavior of firms and related network participants. These rules and norms also act as the conduits along which mutual trust is established and tacit knowledge flows through networks.

The above circumstances and processes are essential in financial center formation and continuation, also referred to as "path dependency» (PorTeous 1999). However, there are also decentralizing forces at work, strengthened by ICTs, leading to an improvement of the position of smaller cities. The decentralizing forces mainly include high costs of operation in large financial centers, congestion costs, and disamenities of life in large cities (Moulaert and Gallouj 1993, Porteous 1999).

\section{Amsterdam as a Financial Center: History}

Already some centuries ago Amsterdam became the financial capital of The Netherlands in close interaction with activities in overseas trade. The basis was laid by colonial trade with the Far East and parts of South America in the 17th to the 19th century, leading to the growth of so-called merchant banks. A number of these banks survived into the 20th century and expanded in the years after the Second World War by adding retail services, thereby capturing the working population as an important group of customers. The growth of the sector in Amsterdam in these years, however, was mainly caused by merging and acquisition undertaken by large banks in Amsterdam. Characteristically, medium-sized and smaller banks in other large cities and in provincial towns were acquired and integrated in Amsterdam banks. For example, in the years between 1950 and 1985, Amsterdam firms were leading in almost $70 \%$ of all take-overs (Table 1). As a result, only a few small and medium-sized banks sur- 


\begin{tabular}{|l|l|l|}
\hline $\begin{array}{l}\text { Location of the leading firm and } \\
\text { acquired firm }\end{array}$ & $\begin{array}{l}\text { Absolute number } \\
\text { of events }\end{array}$ & Percentage \\
\hline Amsterdam - Outside Amsterdam & 65 & 50.4 \\
\hline Amsterdam - Within Amsterdam & 23 & 17.8 \\
\hline Rotterdam - Outside/Within Rotterdam & 22 & 17.1 \\
\hline Leading party located elsewhere & 19 & 14.7 \\
\hline Totals & 129 & 100.0 \\
\hline
\end{tabular}

Tab. 1: Take-overs regarding location of firm (1960-1985)

(Time-series published by the Nederlandsche Bank end in 1985)

Prises de pouvoir au regard de la localisation de firmes (1960-1985)

Firmenübernahmen in Bezug auf den Standort

Source: adapted from van GEENHUIZEN 1993

vived as independent banks outside Amsterdam, particularly in the other large cities.

A second process reinforced the growth of financial services in Amsterdam, i.e. the attraction of foreign banks. Foreign banks started to establish themselves in The Netherlands in the 1960s. These were predominantly American and British initiatives, followed by Japanese ones, aimed at expanding the market and serving large firms from the home country. Amsterdam has been the absolute leader in attracting foreign banks, with a share of more than $80 \%$ of all new establishments in The Netherlands (Table 2). This pattern is also true for full branches and representative offices of foreign banks in the Netherlands.

By means of in-depth interviews, the relevance of agglomeration economies and knowledge spillovers could be confirmed (van Geenhuizen 1993, Hart, Ter \& Piersma 1990). Accordingly, essential activities are performed by Amsterdam Exchanges, like the official Dutch share market, bond market, options market, financial futures market and agricultural futures market. The presence of a large number of brokerage firms and various specialized services is also important. The same holds for the specialization in the labor market of Amsterdam in terms of finance professionals and related professionals.

\section{Amsterdam in the National Context}

One can observe an important increase of jobs in financial services in Amsterdam in the past decade (by $20.4 \%$ ) (Table 3). However, the share in the regional economy of these services has remained the same and this is also true for the share of financial services in Amsterdam at the national level. This pattern indicates the absence of structural changes.

Headquarters of banks in The Netherlands are mainly located in Amsterdam as the end-result of the previously discussed acquisition activity undertaken by

\begin{tabular}{|l|l|c|}
\hline City of establishment & Absolute numbers & Percentage \\
\hline Amsterdam & 24 & 66.7 \\
\hline Amsterdam (headquarter) and Rotterdam & 6 & 16.7 \\
\hline Rotterdam & 3 & 8.3 \\
\hline Rotterdam (headquarter) and Amsterdam & 3 & 8.3 \\
\hline Totals & 36 & 100.0 \\
\hline
\end{tabular}

Tab. 2: Establishment of foreign banks regarding location (1960-1985)

L'implantation de banques étrangères au regard des facteurs de localisation (1960-1985)

Niederlassungen von ausländischen Banken in Bezug auf den Standort

Source: adapted from vaN GEENHUIZEN 1993 


\begin{tabular}{|l|l|l|}
\hline Employment indicator & 1991 & 1999 \\
\hline Number of jobs (x 1.000) & 44,6 & 53,7 \\
\hline Share in regional economy (\%) & 8.2 & 8.0 \\
National reference value (\%) & 3.7 & 3.8 \\
\hline Share in national sector (\%) & & \\
\hline
\end{tabular}

Tab. 3: Development of financial services employment in the region of Amsterdam

(In 1994 a new system of Standard Industrial Classification was introduced. Although care has been taken to choose classes as similar as possible to previous years small deviations may occur. No data available for 2000.)

Développement de l'emploi dans les services financiers de la région d'Amsterdam

Beschäftigungsentwicklung im Bereich Finanzdienstleistungen im Grossraum Amsterdam

Source: STATISTICS NeTHERLANDS

banks in Amsterdam and the entry of foreign banks here. By the end of the $1980 \mathrm{~s}, 61.0 \%$ of the headquarters of the 40 largest banks were in Amsterdam (Table 4).

The pattern for 1999 indicates a small move downward in the city-system, i.e. an increase of almost $10 \%$ for small and medium-sized towns $(<200.000$ inhabitants) (Table 4). One can argue that the use of ICTs enables new head-offices of certain banks to operate at a distance from Amsterdam. In fact, this matches with the nature of some newcomer banks in smaller cities developed from domestic insurance and savings. These banks serve the domestic retail and business market, which may imply mainly routine contacts with services in Amsterdam. The small spread of headquarters can also be ascribed to a rapid integration of banks in Amsterdam based upon previous mergers and acquisitions, and a withdrawal of some foreign banks from The Netherlands (mainly Japanese banks) due to rationalization. When considering the share of the national balance sheet total in Amsterdam, however, it becomes clear that concentration has increased in the past decade. Amsterdam's share in the national total of financial services has grown from 52.3 to $63.8 \%$. This development can in part be explained with the merger in 1990 between Algemene Bank Nederland $(\mathrm{ABN})$ (headquarters in Amsterdam) and Amsterdam-Rotterdam Bank (AMRO) (headquarters mainly in Rotterdam) which has brought the corporate headquarters of the, since then, largest Dutch bank (6th on the world list) to Amsterdam. That Amsterdam has still not lost its attractiveness is clearly indicated by the most recent move of the international headquarters of RABO Bank (32nd on the world list) from Utrecht to Amsterdam. The motives behind this

\begin{tabular}{|c|c|c|c|c|}
\hline $\begin{array}{l}\text { City-size } \\
\text { (inhabitants x 1000) }\end{array}$ & $\begin{array}{l}1989 \\
\% \text { of } \mathrm{HQ}\end{array}$ & $\%$ of BST & $\begin{array}{l}1999 / 2000 \\
\% \text { of HQ } \\
\end{array}$ & $\%$ of BST \\
\hline$<50$ & 2.4 & 0.1 & 5.1 & 0.1 \\
\hline $50-200$ & 7.3 & 1.5 & 12.8 & 3.0 \\
\hline $200-300$ & 7.3 & 19.9 & 7.7 & 24.1 \\
\hline $400-600$ & 22.0 & 26.2 & 20.6 & 9.0 \\
\hline$>600$ & 61.0 & 52.3 & 53.8 & 63.8 \\
\hline TOTALS & 100.0 & 100.0 & 100.0 & 100.0 \\
\hline
\end{tabular}

Tab. 4: Distribution of bank headquarters (HQ) and connected balance sheet total (BST) in the Netherlands (40 largest, independent banks)

Répartition des quartiers généraux de banque (HQ) et bilan total (BST) aus Pays-Bas (les 40 plus grandes banques indépendantes)

Verteilung der Bank-Hauptfilialen und diesbezüglicher Anteil an der Gesamtbilanz in den Niederlanden (40 grösste unabhängige Banken)

Source: based on data from Netherlands Institute for Banking and Stockbroker Firms 


\begin{tabular}{|c|c|c|}
\hline Exchange & $\begin{array}{l}\text { Companies listed (stock } \\
\text { exchange) }^{(\text {a) }} \\
1990 \quad 1999 \\
\end{array}$ & $\begin{array}{l}\text { Total value of share trading } \\
\times \begin{array}{l}\text { x } 1000.000 \$^{(c)} \\
1990\end{array} \\
\end{array}$ \\
\hline London & 2,274 & 3399,381 \\
\hline Paris & 1,144 & $628,611^{(\mathrm{d})}$ \\
\hline German Exchanges & 851 & 1551,467 \\
\hline Amsterdam & $387^{(b)}$ & 471,226 \\
\hline Swiss Exchanges & 412 & $117,752^{(\mathrm{d})}$ \\
\hline Madrid & 727 & 738,726 \\
\hline Brussels & 268 & 221,365 \\
\hline Stockholm & 300 & 313,678 \\
\hline Copenhagen & 284 & 66,605 \\
\hline Italian Exchanges & 220 & n.a. \\
\hline
\end{tabular}

Notes: a) excluding investment funds b) Figures from 1996 onwards cannot be compared with previous ones. c) including investment funds, calculated according to REV system d) 1993/1994

Tab. 5: European financial centers according to stock exchange activity

Les centres financiers européens d'après l'activité boursière

Europäische Finanzzentren in Bezug auf den Börsenhandel

Source: International Federation of Stock Exchanges (FIBV)

relocation are to concentrate activities in one location (formerly dispersed in Utrecht), to benefit from the more specialized labor market in Amsterdam and to benefit from physical presence and from communication of corporate identity among other banks in Amsterdam (newspaper coverage).

\section{Amsterdam in an International Context}

The next indicator of the position of Amsterdam is (inter)national stock exchange activity. It needs to be mentioned that comparing this activity across different European cities is difficult because figures are increasingly presented as a set of national exchanges that co-operate, instead of exchanges in single cities. Given this limitation, one can observe a third position of Amsterdam in 1990 in terms of companies listed and a fourth or fifth position in terms of total value of trade (Table 5). In the 1990s, Amsterdam dropped its rating and moved to an overall sixth place while various other exchanges caught up, such as Swiss Exchanges (mainly Zurich) and Madrid.

What is hidden in the data is that Amsterdam substantially lost to London when a fully automated screen based trade system was introduced there (1986). In fact, Dutch investors could avoid paying commission to intermediaries in Amsterdam by trading Dutch shares via the London Exchange. This development illustrates that particular financial firms run their routine exchange activity by screen in alternative places, i.e. the cheapest ones in terms of charge for commission. Amsterdam has responded to this development by a significant move towards specialization in trade in options and futures. Nowadays, Amsterdam has the second largest exchange in this segment in Europe (van GeENHUIZEN 1999). A certain weakening of the position of Amsterdam in Europe is also evident in the number of top 500 banks currently located in the city, i.e. 40 as compared to 201 in London and 107 in Frankfurt. Thus Amsterdam ranks ninth (Grote 2000). It is not quite clear how the previous patterns may change in the near future after the merging of exchanges in Europe, with Amsterdam Exchanges partaking in EURONEXT together with Paris and Brussels.

\section{Amsterdam in the E-economy}

Banking organizations are currently in a process of adjustment to meet the new circumstances induced by a growing e-economy. The connected changes in the strategy of established «brick and mortar banks» are the following (The BANKer, July 1999, RADECKI et al. 1997, WestLand \& Clark 1999):

- Banks are transforming into multi-channel banks, including local offices, mobile phone, cash dispensers, Internet, etc., to support different customer segments.

- Banks are defining new roles for themselves in the new customer driven value chain, ranging 
from relatively simple information supply to meet customer demand to advanced roles in intermediary activity, such as in electronic auctions and in electronic incubators for new firms.

- Banks are becoming involved in a «web» of alliances and newly established firms to secure the roles they want to play, such as with Internet firms (providers, portals, etc.), online banks and specialized suppliers in order to add innovative services to their portfolio.

- Banks continue to be involved in mergers and acquisition (increasingly cross-border ones) in order to create sufficient scale for investment in the necessary transformation.

Threats come particularly from new e-banks that «eat» into retail market shares of established banks because they can offer better services for certain products and charge less commission. There is also heavy competition in the division of new roles in the emerging online markets, such as the role of information agent, activity in e-commerce and e-auctions. In addition, a substantial part of the exchange trade, i.e. routine-based, may become footloose using screen based trade in the cheapest place on the globe. Established banks which cannot adapt in time are forced to merger, or disappear. However, one may expect banks in financial centers to continue to profit from the local «milieu» during this adjustment process, a situation that most probably will lead to more specialization in global markets. The benefits mainly affect factors which remain localized, such as specialized workers and non-routine information. Accordingly, in contrast to the «death of cities» and «global urban centers» scenarios, the future in Europe seems more likely to be one of large cities and some smaller cities.

In the past few years, Amsterdam has developed the ambition to become one of Europe's ICT-capitals. Currently, a conglomerate of large and small ICTfirms is emerging on the southern edge of the city, based on access to one of the most advanced Internet connections (Watergraafsmeer) (GIGAPORT 2000) and proximity to the international airport of Amsterdam (Haarlemmermeer). This activity is partly linked with the financial sector, partly with other ones like publishing and international trade (KPMG-BEA 2000). What this sector shares with financial services is similar levels of uncertainty and need for support from the local environment to increase competitiveness in global markets.

It is quite difficult to estimate the size of ICT-activity to date because statistical categories do not match with the phenomena involved. The sub-sector Computer Service and Information Technology is clearly too narrow while much broader categories, e.g. including multi-media tools, broadcasting, related content activity, etc., suffer from «noise». But if a narrow definition is used, important dynamics can be observed in Amsterdam in the past five years. There is an increase of jobs by $136 \%$, along with a trend for concentration in Amsterdam, as witnessed by an increase of shares in national totals from $14.1 \%$ to $17.2 \%$ (STATISTICS NETHERLANDS).

In a comparative study with other European cities and New York, the potentials of Amsterdam to realize further ICT ambitions have been assessed as follows (KPMG-BEA 2000):

- In terms of demand, the small national market can be seen as a disadvantage but there are many relations outside the ICT-sector and abroad -some of them reflecting international appreciation.

- There is still small attention for networking and partnerships, and this conforms with the idea of a weakly developed economic complex.

- There is a modest self-image of the sector concerning innovation and competition, strongly linked to recent initiatives, i.e. support from the public sector and establishment of a network for knowledge exchange and cooperation.

- The strength of Amsterdam resides in a relatively strongly developed base of creative and content industry (publishers, advertising, etc.) aside from communications and computing, and financial services.

- Positive location factors are an excellent infrastructure, including the Internet hub providing direct access to the newest broadband technologies. Favorable are also the good Internet culture and the many English speaking people in the labor market. We may add the international character of Amsterdam, with $45 \%$ of its population of non-Dutch origin and the large openness of the national culture to foreign influences (Municipality of Amsterdam 2001).

- Negative location factors are a weak image as an ICT-city and, more importantly, shortcomings in the labor market, i.e. a general shortage of ICT specialists and a shortage of such specialists with a strong focus on ICT practice (NRCHandelsblad, August 15th 2001). There are also specific shortcomings in the real estate market, i.e. a shortage of up-market housing and a shortage of specific office locations.

From the above it may be concluded that there are sufficient opportunities for growth of ICT-activity, but that the shortcomings in the labor market and real estate market, as well as the weakly developed networking and synergy have a hampering effect. 


\section{Conclusion and Policy Implications}

The previous sections have shown that Amsterdam has somewhat strengthened its position as the major node in the national financial system, whereas it is losing influence in the European context. Given the fact that the Dutch economy is relatively small and no major international financial institutions are located here, the response may be in a further specialization, and activities in global markets. In addition, the emergence of the e-economy and need for strategic transformation cause a range of new opportunities and threats for financial services. The analysis has shown that in the past years financial firms have been able to benefit from agglomeration economies and knowledge spillovers in Amsterdam. Attention will need to be paid to preserving this local supportive «milieu» and to adjusting it to the new needs in the e-economy. This situation calls for a strong knowledge policy in the Amsterdam region, to be addressed to municipalities and Chambers of Commerce as facilitating and stimulating actors, but also to universities and higher educational institutes and large firms. The following approach and ingredients are essential in such a knowledge policy (vaN GeENHUIZen \& NiJkamp 2000, van Geenhuizen \& Ratti 2001, KNIGHT 1995, KPMG-BEA 2000):

- An integrated approach, including, for example, education and culture, physical planning and urban architecture, labor market and housing market policy - the latter in order to satisfy the needs of knowledge workers. In such an approach the focus is particularly on impacts from interrelations between the policy fields.

- A learning approach, meaning that research needs to be done on the location behavior of new firms and the rise of new locational needs, for example, in terms of business locations and supporting services. In the meantime, policies need to be flexible to enable adjustment to emerging new insights.

- To reduce shortcomings in the labor market and real estate market, e.g. to increase education and training in specific fields, to increase housing construction for higher income groups using international standards, and to increase supply of offices for firms in different development stages.

- With regard to existing networks supporting financial services, to continue to facilitate meeting places in the inner city area, such as by preserving attractive (semi)public places, and, more importantly, to advance cooperation between actors and networks where new synergy can be achieved, such as by organizing expert meetings, business visits and business presentations, particularly about e-banking activity.

- To advance a further increase of internationally acknowledged expertise in financial markets and services. This may be organized within the existing Amsterdam Institute of Finance (AIF), and focus on ongoing and emerging specialization in Amsterdam, like trade in options and futures and trade in debts, «green» investments and e-banking.

- With regard to new networks, to create conditions to develop the networks needed, e.g. places for professionals to meet informally on spots at the southern edge of Amsterdam, international meetings in Amsterdam and business events in Amsterdam, the latter to bring new firms into contact with each other. The activity of an «animator» may be helpful here. Animators organize the structure in which networks can develop. Besides all practical activity connected with meetings, they diffuse information, open doors, get political support, monitor processes, and motivate people to become involved and to follow their promises.

With Amsterdam's excellent infrastructure, including an advanced Internet node available only in a limited number of places in Europe, it seems that the foreseeable future will continue to show a strong position of Amsterdam. Whether this will also lead to a structural position amongst the top European cities is mainly dependent on timely innovation, strategic acquisition and partnerships associated with the e-economy. The supportive role of urban policy is very important here, for example, to improve knowledge about new locational needs, to prevent particular shortcomings and reinforce particular strengths.

\section{Literature}

ArThuR, B. (1996): Increasing returns and the new world of business. - In: Harvard Business Review, JulyAugust: 100-109.

AudRETSCH, D. B. (1998): Agglomeration and the location of innovative activity. - In: Oxford Review of Economic Policy 14: 18-29.

The Banker (1999): The dawn of a new e-economy. July 1999.

Bolisani, E. \& E. Scarso (2000) Electronic communication and knowledge transfer. - In: International Journal of Technology Management 20,1-2: 116-133.

Cairncross, F. (1997): The Death of Distance. How the Communications Revolution Will Change Our Lives. Cambridge MA: Harvard Business School Press.

Geenhuizen, M. van (1993): A Longitudinal Analysis of The Growth of Firms. - Rotterdam: Erasmus University (Ph.D. thesis).

Geenhuizen, M. van (1999): Shifts in Urban Hierarchy: The Case of Financial Services in the Netherlands. - In: Geographica Polonica 72,1: 107-124. 
Geenhuizen, M. van \& P. Nijkamp (2000): The learning capability of regions: conceptual patterns and policies. - In: Boekema, F. et al. (eds): Knowledge, Innovation and Economic Growth: Theory and Practice of the Learning Region. - London: Edward Elgar Publishing: 38-56.

Geenhuizen, M. van \& P. NiJkamp (2001): Electronic Banking and the City System in the Netherlands. - In: BrunN, S. \& T. LeINBACH (eds): The Wired Worlds of Electronic Commerce. - London: John Wiley: 181-201. Geenhuizen, M. van \& R. RatTI (2001): Gaining Advantage from Open Borders. An Active Space Approach to Regional Development. - Avebury: Ashgate.

Gigaport (2000): Gigaport. The new generation of Internet in The Netherlands (in Dutch). - http://www. gigaport.nl, 5.10.2000.

GLAESER, E.L. (1998): Are cities dying? - In: Journal of Economic Perspective 12,2: 139-160.

Graham, S. \& S. Marvin (1997): Telecommunications and the City. Electronic Spaces, Urban Places. London: Routledge.

Graham, S. (1999): Global Grids of Glass: On Global Cities, Telecommunications and Planetary Urban Networks. - In: Urban Studies 36,5-6: 929-949.

GROTE, M.H. (2000): Frankfurt - An Emerging International Centre. - Frankfurt: Johann Wolfgang GoetheUniversität, IWSG Working Papers 10-2000.

Hart, H., Ter, W. \& J. Piersma (1990): Direct Representation in International Financial Markets: The Case of Foreign Banks in Amsterdam. - In: Journal of Social and Economic Geography 2: 82-92.

HIPPEL, E. VON (1994): Sticky information and the locus of problem solving: implications for innovation. - In: Management Science 40: 429-439.

KNIGHT, R.W. (1995): Knowledge-based development: policy and planning implications for cities. - In: Urban Studies 32: 225-260.

KPMG-BEA (2000): ICT in Amsterdam and Haarlemmermeer as compared with New York, London, Frankfurt and Stockholm (in Dutch). - Hoofddorp: KPMG-BEA.

LAmBooy, J.G. (1998): Polynucleation and Economic Development: The Randstad. - In: European Planning Studies 6,4: 457-466.

Leyshon, A. \& N. Thrift (1997): Money/Space. Geographies of Monetary Transformation. - London: Routledge.

Martin, R. (ed.) (1999): Money and the Space Economy. - Chichester: Wiley.

Mitchell, W.J. (1995): City of Bits; Space, Place, and the Infobahn. - Cambridge: The MIT Press.

Moulaert, F. \& C. Gallouj (1993): The Locational Geography of Advanced Producer Firms: The Limits of Economies of Agglomeration. - In: Daniels. P. et al. (eds): The Geography of Services. - London: Frank Cass: 91-106.
Municipality of Amsterdam (2001): http://www.ez. amsterdam.nl, 25.7.2001.

Porteous, D. (1999): The Development of Financial Centres: Location, Information, Externalities and Path Dependence. - In: Martin, R. (ed.): Money and the Space Economy. - Chichester: John Wiley: 95-114.

NRC-Handelsblad (2000): A New Golden Age (in Dutch). - 15.8.2000.

RADECKI, J., WENNIGER, J. \& D. ORLOW (1997): Industry Structure: Electronic Delivery's Potential Effects on Retail Banking. - In: Journal of Retail Banking Services XIX,4: 57-63.

SASSEN, S. (1999): Global Financial Centres. - In: Foreign Affairs 78,1: 75-87.

Statistics Netherlands (various years): Survey on Employment and Incomes. - Voorburg and Heerlen. WestLAND, J.C. \& T.H.K. Clark (1999): Global Electronic Commerce. Theory and Case Studies. - Cambridge MA: The MIT Press.

\section{Summary: Amsterdam as a Changing Node in Financial Services}

In this paper the development of Amsterdam as a node in financial services is investigated. The context is one of competition between large and smaller cities, based on changing location factors and use of information and communication technologies (ICTs). The analysis of the development of Amsterdam starts with an historical explanation of the concentration of financial services here. It proceeds with a discussion on the changing position in the past decade, both in the national and European system of cities. Further, various strategic adjustments by financial firms connected with the e-economy are identified. The results of the study indicate that the position of Amsterdam in the Dutch urban system is not challenged. Among European cities, however, Amsterdam is trying to regain ground by specialization and moving to partly related ICT-activity. The latter shift is supported by an excellent infrastructure and the open and international character of the city and its population. But there are also less favorable conditions, such as in the labor market and real estate market. The paper concludes with some of the implications for urban policy.

\section{Zusammenfassung: Amsterdam als ein sich wandelnder Knotenpunkt im Finanzdienstleistungsgeschäft}

In diesem Beitrag wird die Entwicklung von Amsterdam als Knotenpunkt im Finanzdienstleistungsgeschäft untersucht. Dies im Kontext des Wettbewerbs zwischen grösseren und kleineren Städten, basierend auf sich ändernden Lokalitätsfaktoren und dem Gebrauch von Informations- und Kommunikationstechnologien (ITCs). Die Analyse der Entwicklung Amsterdams beginnt mit einer historisch begründeten Erklärung der Konzentration der Finanzdienstleistungen in Amster- 
dam. Im weiteren wird die sich ändernde Position im letzten Jahrzehnt diskutiert, jeweils im Hinblick auf das nationale und europäische Städtesystem. Anschliessend werden verschiedene strategische Umstrukturierungen der im Finanzdienstleistungswesen tätigen Firmen im Zusammenhang mit der e-economy beleuchtet. Die Untersuchungsergebnisse zeigen, dass die Stellung Amsterdams im holländischen System unbestritten ist. Innerhalb der europäischen Städte jedoch scheint Amsterdam etwas an Bedeutung verloren zu haben. Es versucht diese durch Hochspezialisierung zurückzugewinnen und indem es sich ferner zu teils verwandten ICT-Aktivitäten hinbewegt. Die letztere Verschiebung wird durch eine hervorragende Infrastruktur und durch den offenen und internationalen Charakter der Stadt und ihrer Bevölkerung unterstützt. Doch gibt es auch weniger günstige Bedingungen, so z.B. auf dem Arbeits- und Grundstücksmarkt. Der Text schliesst mit einigen Folgerungen für die Stadtpolitik.

\section{Résumé: Amsterdam, un site nodal en voie de muta-} tion dans le secteur des services financiers

La présente contribution observe l'évolution d'Amsterdam en tant que point nodal du secteur des services financiers, dans le contexte de la compétition entre les grandes et les petites villes, sur la base de l'évolution des facteurs de localisation et du recours aux technologies de l'information et de la communication (ITCs). L'analyse de l'évolution d'Amsterdam commence par une explication historiquement fondée de la concentration des services financiers dans la ville. Elle donne lieu en outre à une réflexion critique sur la position en voie de changement de celle-ci durant la décennie écoulée, à la fois dans l'optique du système urbain national et européen. Puis diverses restructurations stratégiques dans les firmes concernées par le secteur des services financiers sont présentées en relation avec l'e-économie. Les résultats de l'étude montrent que la position d'Amsterdam demeure incontestée dans le système hollandais. Dans le cadre des villes européennes toutefois Amsterdam semble avoir perdu quelque peu en importance. La ville tente cependant de remonter la pente par une haute spécialisation, notamment en s'orientant partiellement vers les activités ICT. Le dernier transfert est sous-tendu par une infrastructure remarquable et le caractère à la fois ouvert et international de la ville, ainsi que par la population de celle-ci. Il existe aussi des conditions de localisation moins favorables, p.ex. sur le marché foncier et celui du travail. Le texte s'achève sur la présentation de quelques répercussions de cette situation sur la politique urbaine.

Dr. Marina van Geenhuizen, Associate Professor, Faculty of Technology, Policy and Management Delft University of Technology, PO Box 5015, 2600 GA Delft, The Netherlands.

e-mail:m.s.vangeenhuizen@tbm.tudelft.nl

Manuskripteingang/received/rentrée du manuscrit: 27.7.2001

Annahme zum Druck/accepted for publication/accepté pour l'impression: 31.10.2001 